\title{
THE ENFORCEABILITY OF ANTENUPTIAL AGREE- MENTS FOR THE RELIGIOUS INSTRUCTION OF CHILDREN
}

\author{
JAMES E. CARTY*
}

The antenuptial agreement for the religious instruction of children generally appears in mixed marriages contracted between Protestant and Catholic parties. The Roman Catholic Church requires that the non-Catholic party sign such an agreement before its consent will be given to the proposed union. The enforceability of this type of agreement would seem to be of interest in view of the increasing num-. ber of mixed marriages. 1 There appears, however, to have been little litigation regarding such agreements. The question of the enforceability of the agreement may arise (1) indirectly where a party seeks custody without referring to the agreement, and (2) directly where the agreement is sought to be enforced irrespective of who has custody.

The American and English and Empire cases will be considered separately. The American cases are in conflict as to the enforceability of antenuptial agreements for the religious education of children, while the English doctrine is that the agreement lacks legal significance and is not eniorceable. As the English and Empire cases antedate the American cases, the former will be considered first in the following order, based on differences in fact situations: (1) cases where both parties to the agreement were dead and the dispute was between the maternal and paternal relatives; (2) cases where one party to the agreement was dead and the other alive, and the dispute was between the latter party and the relatives of the deceased; and, (3) cases where the parties to the agreement were both alive and involved in the litigation. The varying fact situations may not have affected the results, but the cases are considered on this

\footnotetext{
* 3rd year law student Duke University; A.B. Washington State Col. lege 1949.

1 Thomas, Some Observations on Mixed Marriages in the United States, (Inst. of Social Studies, St. Louis Univ. 1951).
} 
basis for purposes of convenience and because there may be different considerations present.

The development of the English doctrine occurred between 1852 and $1878 .^{2}$ In re Brown ${ }^{3}$ appears to have been the basis for the English cases. The court found there was no antenuptial agreement but, nevertheless, laid down the "practical argument" against enforcement. The court doubted its ability to enforce an agreement of this type wondering if the family would have to be broken up to prevent violation of the agreement and difficulty was forseen in attempting to force a father to furnish funds for the education of his child in a religion with whose principles he was in disagreement. The court could not see itself lodging a father in jail for life unless he consented to his child being brought up in a faith he believed unscriptural and destructive of the child's eternal welfare and for not furnishing the funds for that purpose.*

The argument does not appear to be sound. A court is generally able to compel a husband to contribute support money when it confronts him with the alternative of imprisonment. The court may have had in mind the desirability of this method of enforcement. As to the possibility of enforcement breaking up a home, this in all probability happened prior to institution of litigation. The court seems to have underestimated both its talents and ability.

\section{Cases Where Both Parties to the Agreement Were Dead}

In re Uren ${ }^{5}$ involved litigation between the maternal and paternal relatives after the death of the parents. It was said that while the agreement was not enforceable weight would be given it, apparently as being indicative of the intent of the parties. The Protestant father had indicated a desire to abide by the agreement. The public authorities were given custody of the children, but it was ordered that

\footnotetext{
2 For an extended analysis of the English cases see: WHITE, THE Legax gffect of ANtenuptial Pronises in Mrxed Marriages (1932).

2 Ir.Ch.R. 151 (1852).

- See In re Agar-Ellis, 10 Ch.D. 60 (1878).

- (1936) Q.S.R. 168, 10 AUsT.L.J. 363 (1936-1937). The antenuptial agreement was between a Protestant man and a Catholic woman.
} 
they be educated as Catholics. The court said that the welfare of the children was to be given great consideration.

In the recent case of In re Collins, ${ }^{6}$ the child had been placed in the care of the Protestant maternal grandparents. Some two years later, the paternal grandparents sought custody so that they would be able to raise the child a Catholic. In the lower court, Chitty, J., construed the agreement as not being between the parties but between the parties and the Catholic Church. The agreement was said to be unenforceable. On appeal, it was held that under the Guardianship of Infants Act of 1925, the welfare of the child was the controlling factor. The maternal grandparents were given custody. Lindley, L. J., said he did not know whether the agreement was a contract between the parties but thought "it rather looks like a condition imposed by a higher power." The result was probably sound as the child had been with the Protestant parties sufficiently long to have become inculcated with Protestant beliefs. It may have been best for the child's welfare to avoid the possible shock which might have attended a change of religion.

\section{Cases Where One Party to the Agreement Was Dend}

The earliest case involving this fact situation seems to have been Hill v. Hill. ${ }^{7}$ The Catholic father died, and the paternal relatives sought to control the religious education of the daughter. The existence of an agreement was not proved, but the court said that if an agreement had been found, there appeared to be no "principle on which the court could not give effect to it."

One of the leading English cases is Andrews v. Salt. ${ }^{8}$ The Catholic father died when the daughter in question was nearly a year old. The father by will named his brother

\footnotetext{
- [1950] 1 All E.R. 1057. The antenuptial agreement was between a Protestant woman and a Catholic man. The father predeceased tbe mother.

740 L.J.Rep. 505 ( 31 N.S.) (1861). The alleged antenuptial agreement was between a Catholic man and a Protestant woman; it was provided that boys be educated as Catholfes and girls as Protestants.

s L.R. 8Ch. 622 (1873). A Catholic man and a Protestant woman entered into an oral antenuptial agreement that the boys were to be educated as Catholics and the girls as Protestants.
} 
testamentary guardian and directed that his children be raised as Catholics. After a lapse of nine years, the brother instituted proceedings to enforce the father's direction. In the meantime, the child had been raised as a Protestant in accordance with the agreement. In the lower court, Malins, $V$. C., said that if such an agreement were established, it would be one to which the court would feel inclined to give effect. On appeal, it was said that such an agreement was not legally binding and that the child is ordinarily to be raised in the religion of the father, but the right of the father could be waived, and in determining whether a waiver had occurred, the agreement was a circumstance to which weight should be attached. The decision was based on the facts that the father had allowed the child to be baptized a Protestant and the laches of the guardian in seeking enforcement of the father's direction. ${ }^{10}$

A similar situation existed in In re Clark.11 The Protestant father abided by the agreement during his life, but after his death, the paternal relatives sought to have the child raised as a Protestant. The antenuptial agreement was held unenforceable, but the court said if, after the father's death, it appeared to be best for the child's welfare that it be educated in the mother's religion and there was a question as to whether the father had waived his rights, an antenuptial agreement would be given great weight. It was decreed that the Catholic instruction be continued on the grounds that (1) the father had waived his rights and

\footnotetext{
- L.R. 8Ch. 628 (1873).

${ }^{10}$ Accord, In re Meades, 5 Ir.R.Eq. 98 (1871), involving an antenuptial agreement between a Protestant man and a Catholic woman; the mother died. A maternal aunt petitioned for custody and asked that the father be restrained from interfering with the Catholic upbringing of the children. The court refused to enforce the agreement on the ground that the father was supreme in matters relating to his children. The court said, "The authority of a father to guide and govern the education of his child is a very sacred thing, bestowed by the Almighty, and to be sustained to the uttermost by human law." Cited in L.R. 10 Ch. 57 (1878).

12 21 Ch.D. 817 (1882). A Protestant man and a Catholic woman signed an antenuptial agreement to the effect that any issue of the marriage would be raised as Catholics.
} 
(2) it was in the best interest of the child that it be brought up as a Catholic.18

Cases Where Both Parties to the Agreement Were Living

The Protestant father in In re Agar-Ellis ${ }^{13}$ instituted proceedings to have the children made wards of the court and to have the question of their religious education settled. In the lower court, Malins, V. C., said the wishes of the father were to control unless: (1) he proposed to raise the children as infidels; (2) there was immoral conduct involved; or, (3) the father had been guilty of abandonment of the parental duty. The Vice-Chancellor said that an antenuptial agreement for religious instruction of children was not enforceable. ${ }^{14}$ The decision granting the father control of the religious education of the children was affirmed largely on the ground of the father's supremacy in such matters. ${ }^{85}$

In Rochfort $v$. Rochfort, ${ }^{16}$ the parents were engaged in litigation for custody of a child of the marriage. A statute

\footnotetext{
${ }^{12}$ Accord, O'Donnell v. O'Donnell, 1918, pt.2 Scots L.T. 233 . The parents were both Catholics. The mother died, and the fathor married a Protestant woman. An antenuptial agreement was signed. The father died. There were no children by the secoud marriage. The Catholic relatives sought custody to ensure that the chlldren were ralsed Catholics. It was said that "prima facie, it is in the best interests of a child that he should be educated in the religion of his parents, or, if there be a difference between the religion of the father and that of the mother, in the religion of the father." The agreemeut was referred to iu order to show the desires of the father in the matter, aud though it was not expressly sald whether the agreement was enforceable, the clear impllcation of the opinion is that such was the court's view. But the court said that the controlling consideration should be the welfare of the children.

${ }^{13}$ Supra, n. 4. The agreement was between a Protestant man and a Cathollc woman with any children of the marriage to be raised as Catholics. The Ohio court in In re Loucks, 10 Ohlo S.\&C.P.Dec. (1889), said that the English courts had gone to the edge of reasoning in sus. taining the supremacy of the father in the religious instruction of the children, citing the present case.

14 Apparently Malins bad undergone a remarkablo motamorphosis after his decision in Andrews v. Salt, supra, n. 8, where he could see no reason for non-euforcement. Some five years elapsed botween that case and the present decision.

15 Accord In re Meades, 5 Ir.R.Eq. 98 (1871).

16 (1944) 61 W.N. (N.S.W.) 125, 18 AusT.L.J. 145 (1944-1945). A Catholic man and a Protestant woman executed an antenuptial agreo.
} 
provided that in such cases, the welfare of the child was to control. Apparently, the father's only interest in the child was that it be raised in his religion. The court was mainly concerned with the welfare of the child and said that the desire of the father for a particular religious upbringing did not equal the desirability of committing the child to the custody of the mother. The antenuptial agreement was said to be of no effect.

It would seem that different policy considerations might be present in the different fact situations outlined above. In the cases where both parties were alive, the court might feel more inclined towards enforcement, inasmuch as the one spouse had probably entered into the marital relationship relying on the promise of the other spouse to raise the children in a particular faith. ${ }^{17}$ Much the same considerations could apply in cases where one of the parties was dead, if the deceased spouse were the one making the promise to educate the child in a particular manner. Where the promising party is the one surviving or where both parents are dead, a further question arises, narnely, who would have standing to enforce the agreement. ${ }^{13}$ A conflict between local law and canon law could arise as the latter obligates the baptismal God-parent to intervene on the death of a Catholic parent to ensure a Catholic home for the child.19

Where the promising spouse is the survivor, sound policy might induce the court to refuse to enforce the agreement. If it were to be held enforceable, a situation might well arise where the survivor, having married one of his own faith, would have his children attending different churches. Such

ment providing that any issue of the union were to be raised Catholics. In addition, the woman signed a subsequent agreement prior to separation promising that the children would be raised as Catholics.

18 Agruably, the situation would be more persuasive to the court where one party to the marriage was a devout Catholic, for that Church imposes the penalty of excommunication on the members thereof who violate the laws of the Church which are especially strict with respect to marriages with non-Catholic parties. Ramon v. Ramon, 34 N.Y.S.2d 100 (1942).

18 Brewer v. Cary, 148 Mo.App. 193, 127 S.W. 685 (1910) where that was the ground of decision.

${ }^{10}$ This was exactly the situation in Brewer v. Cary, supra, $\mathbf{n} .18$. 
a situation would present great practical difficulties, and it might be sound policy to hold the agreement unenforceable in that case.

The English rule, then, is that an antenuptial agreement for the religious instruction of children is not enforceable. ${ }^{20}$ It appears there are valid reasons why the English rule would be of doubtful applicability as precedent in American courts. The rule received its impetus from the 1852 case of In re Browne. At that time, and for some years subsequent thereto, factors prevailed different from those obtaining today: (1) the father was deemed to be the supreme authority in family affairs. ${ }^{21}$ But today in England this is changed by the Guardianship of Infants Act of 1925 and similar statutes. Like legislation has been enacted in the United States. ${ }^{22}$ It would seem that this reason for the rule against enforceability would be of little importance today. (2) Hostility to Catholicism was prevalent at the time the early cases were decided. But this has decreased in recent years. ${ }^{23}$ Today, the climate would be more favorable to holding an agreement enforceable. (3) The idea that enforcement would lead to broken homes was relied on in support of the

: In addition to the above cited cases, there are other English cases which have been cited for the proposition, but their authority is doubt. ful. See, Stourton v. Stourton, 8 De G.M.\&G. 760, 44 Eng. Rep. 583 (1857) where the parents were both Catholics at the time of the marriage, and there was no antenuptial agreement; D'Alton v. D'Alton, 4 P.D. 87 (1878) involved an agreement made after marriage and in consideration of the wife's reconciliation with an adulterous husband; Hawksworth v. Hawksworth, L.R. 6 Ch. 539 (1871) involved a mixed marriage, but there did not appear to have been an agreement-the child was ordered to be raised in the religion of the Catholic father; In re Nevin, [1891] 2 Ch. 299 where the court relying on Andrews v. Salt, did not bother to decide whether there was a contract or not bofore holding it unenforceable.

2 E.g. In re Agar-Ellis, supra, n. 13. In re Browne, supra, n. 3.

22 In re Carroll, [1931] 1 K.B. 317. "In most American states, statutes have been passed giving parents equal powers, rights and duties in regard to their children." Note, Validity of an Antenuptial Contract Concerning the Religious Instruction of Children, 28 VA.L.REv. 1131 (1942).

23 Friedacan, Parental Right to Control the Religious Eduoation of $\triangle$ CHIDD, 29 HAR.L.R. 485 (1915.1916). 
rule. ${ }^{24}$ The fears of the court were more imaginary than real in this connection. It is difficult to conceive of a situation where home life has remained tranquil until the time of the suit. It would seem that the opposite would be truethat the home would be badly disrupted before the parties felt compelled to resort to litigation. It appears, therefore, that this reason for the rule was not valid in the first instance. (4) The professed inability of the court to see how the decree could be enforced was also urged in support of the rule.25 It is difficult to imagine why a court should have more difficulty in enforcing an agreement of this type than any other agreement. One might suspect that the courts were studiously underestimating their ability.

In view of these considerations, it is difficult to see how, in the light of present conditions, the English cases could serve as useful precedent for an American decision. In addition, the older cases would appear to be no longer applicable in England in view of changed circumstances. No matter what view one takes of the results in the English cases, the reasoning therein may well be deemed to have been faulty.

The American decisions are not in accord as to the legal significance of an antenuptial contract for the religious instruction of children. The reports are relatively free of cases on the subject. This may be due to two reasons; the latter probably being the more important: (1) the compromise of religious differences by way of an antenuptial agreement permanently settles the question to the satisfaction of the parties ; or (2) enforcement might not be sought in case of a disagreement because of a belief that the agreement lacks legal significance, especially in view of the English decisions. The American cases will be considered in two groups: (1) the cases holding antenuptial agreements for the religious instruction of children unenforceable; and (2) the cases holding such agreements to be enforceable.

24 See supra, n. 20.

¿s See supra, n. 20. 


\title{
The Cases Holding Antenuptial Agreements for the Rell- gious Instruction of Children To Be Unenforceable
}

Both parties to the agreement were dead in In re Turn$e r \cdot{ }^{26}$ The Protestant father had predeceased the mother. The paternal and maternal grandparents both applied for guardianship. Under state law, the father had power to dispose of the guardianship of his children by will but had not done so. In searching for evidence of the father's intent in the matter, the court considered the agreement and said,

\begin{abstract}
"The father ... has expressed no wish ... I cannot regard his promise to the priest at his marriage, as expressing a wish; the circumstances under which it was exacted, would by no means allow it to be considered as the expression of his desire or conviction. The fact that he consented to its baptism in the Roman Church, is of more weight, and yet cannot be regarded as the expression of a desire ..."
\end{abstract}

The view that the promise was to the priest is interesting. It was held that the father who knew the views of the mother had expressed no desire, and it could be inferred from this that he desired the wishes of the mother to control. It was said that the wishes of the mother might not be followed "if it clearly appeared that the interest of the infant required her wishes to be disregarded." The maternal grandparents were awarded custody.

In Brewer v. Cary ${ }^{27}$ after the death of the mother, the maternal grandfather who was God-father to one of the children brought a bill in equity against the Protestant father who was raising the children as Protestants in violation of the agreement. The petition was that the court order the children to be brought up as Catholics. The case was decided on the father's demurrer that the court lacked jurisdiction, for under state law, the grandfather did not

${ }^{26} 19$ N.J.Eq. 433 (1868). The agreement was between a Protestant man and a Catholic woman with the children to be raised as Catholics. The will of the mother directed that the children be raised as Catholics, and she named her parents guardians.

zr Supra, n. 18. An agreement between a Protestant man and a Catholic woman. 
have standing to maintain the action. This was the sole point involved in the decision, but in passing, the court considered the legal significance of the agreement. ${ }^{28}$ The court quoted with approval a text statement that "permanent transfer of the natural rights of a parent" was against public policy, and the agreement was said to be unenforceable at law or equity. It was said that if it were deemed an enforceable contract, the law might regard it as entered into by the mother for the benefit of the children and enforceable in a suit by the children in affirmance of their right. Assuming an enforceable right had been conferred on the wife, the court did not feel that it would be a property right passing to and enforceable by the executor or administrator of the deceased wife. ${ }^{29}$

\section{The Cases Holding Antenuptial Agreements for the Reli- gious Instruction of Children To Be Enforceable}

In re Loucks ${ }^{30}$ involved a situation where the parties to the agreement were dead. After the children had been away from the Catholic Church for several years, the Catholic relatives instituted proceedings to have the children raised as Catholics in accordance with the agreement. It

${ }^{29}$ Andrews v. Salt, supra n. 8; In re Agar-Ellis, supra n. 4; and In re Nevin, [1891] $2 \mathrm{Ch} .299$ were relied on by the court after it had previously noted that "Justice Talfourd's Act' (2 \& 3 Vict. c. 54)" had practically overturned the rule of the father's supremacy in family matters. It will be noted that this old rule had a great deal to do with the results in the cited cases.

${ }^{20}$ In re Butcher's Guardianship, 266 Penn. 479, 109 A. 683 (1920). The antenuptial agreement was between a Protestant man and a Catholic woman. The mother predeceased the father who, before his death, had expressed a desire that the children be raised as Catholics. The Protestant grandfather was awarded custody. This was upheld. The statute provided that in the appointment of guardians, persons of the same religious persuasion as the parents were to be preferred. The court said the father's "wish" did not bring him within the meaning of the term "persuasion" and that anyhow the statute was not mandatory as the word "preferred" had been used therein and it was not a mandatory word. The court did not pass on the enforceability of the agreement.

${ }^{20} 10$ Ohio S.\&C.P. Dec. 1 (1889). The case involved an antenuptial agreement between a Protestant man and a Catholic woman. The mother died. After indicating intent to disregard the agreement, the father died. 
was said to be best for the children to leave them as they were and that the agreement did not work as an estoppel among the relatives. The laches of the Catholic parties had a great deal of effect in determining the result of the case. The court, however, discussed the legal effect of the agreement saying it was based on high and sacred consideration and that its binding force and inviolability would be recognized by all courts and sanctioned by the moral sense of mankind. If the litigation were between the parties to the agreement, the court, by way of dictum, said it would fail in its duty if it did not make the agreement work an estoppel of the right of the father to change the course of religious instruction provided for therein. ${ }^{31}$

In Denton $v$. James, ${ }^{32}$ an antenuptial agreement for the religious instruction of children was said to be a "commendable compromise." Though clearly implying that had the litigation been between the parties to the contract it would have been held enforceable, the court said that on the death of the Catholic mother "the father's right to educate his child became paramount, and the agreement was merely persuasive upon him."

st See, Commonwealth v. McClelland, 70 Penn.Super. 273 (1918). The court had before it an antenuptial agreement between a Protestant man and a Catholic woman. The father died. Tho mother was insane. The children had been in the custody of a Protestant party for some years and had acquired a marked anti-Catholic attitude. $A$ maternal aunt instituted proceedings looklng toward the Catholic education of the chlldren in accordance with the agreement. The lower court denied the request and by way of dictum said the children could have been brought up as Catholics early in life and that had "the father ... . raised any objection ... his stipulation entered into at the time of the marriage would have been a sufficient answer." The appellate court adopted the lower court decision in a short per curiam opinion.

32107 Kan. 729, 193 P. 307 (1920). The usual antenuptial agreement was involved. The Catholic mother died. Custody was divided between the maternal and paternal grandmothers. While she had custody, the paternal grandmother adopted the child. The Catholic maternal grandmother instituted the proceedings to attack the regularity of the adoption.

T3e prevalence of dictum in this branch of the law is very evident. The court in In re Lamb's Estate, 139 N.Y.S. 685 (1912) cited the English rule that this type of agreement was not enforceable and said that the "conclusion ... does not appeal to me. of course, such a rule could not be the law of this state." An antenuptial agreement for the religious 
Ramon v. Ramon ${ }^{34}$ is the leading decision holding an antenuptial contract for the religious education of children enforceable. The agreement was between a Protestant woman and a Catholic man. The parties had separated, and the wife had instituted an action for support. As a defense, the husband relied on breach of the agreement. After litigation had started, the parties entered into an agreement whereby the child was to be placed in a Catholic boarding school with the father paying the expenses. This gave effect to the antenuptial agreement. The court approved the arrangement. $^{35}$

It was said that recognition by American courts of the right of a Catholic party to a marriage as a matter of sound public policy to determine the religion of any issue of the

instruction of children was not involved. The remarks were dictum. In Denton v. James, supra, n. 32 the implication that the agreement would be enforced in an action between the parties thereto was not necessary to the decision. Weinberger v. Van Hessen, 260 N.Y. 294, 183 N.E. 429 (1932) did not involve an antenuptial agreement, but it was stated that such agreement had in general been held valid. The court cited 12 A.L.R. 1146, 29 Har.L.R. 485 and Denton r. James, supra, n. 32, the latter citation (and quite arguably the A.L.R. citation) constituting a compounding of dictum on dictum.

s Supra, n. 17. The court said (page 104) that, "The antenuptial agreement ... contemplated the preservation of the spiritual rights and status of the respondent and those of his prospective children. These rights though spiritual and intangible became for all purposes just as real, protective and enforceable as pertained to any physical property ... [The father] had the legal, equitable and constitutional right to protect, to preserve and to maintain inviolate his membership in the Roman Catholic Church. He had the undoubted right to enter into any agreement which would insure to him the continued enjoyment of its privileges and its protection ... He had the right to determine that in his married life he would continue as formerly to abide hy its rules, obligations and discipline. He had the right to seek to preserve this advantage for his children. . . He had the right to choose for a spouse one who, though not Catholic, would at least agree not to interfere in the exercise by him of his solemn religious duties, the most important of which would be to see that his children were brought up in the Catholic faith. ... [Italics by the court.]

i Marriage was said to be a natural right, not created by law but existing before all law. The rights arising out of the marriage relationship were denominated "rights of personality." The reciprocal duties of husband and wife were said to constitute property. Citing Jaynes $v$. Jaynes, 39 Hun.(N.Y.) 40 (1886). For the same view see, Shearer $\mathrm{v}$. Shearer, 73 N.Y.S.2d 337 (1947). 
marriage whether or not there is an antenuptial contract might have arisen from the recognition of three "fundamental principles": (1) such antenuptial agreements are exclusively a Catholic rule; (2) the Catholic Church is the only Christian church holding marriage indissoluble and a sacrament; and, (3) under the natural law, procreation of children being the object of marriage, the permanency of the marital relationship is the foundation of the social order. The agreement was said to be founded on and rooted in the canon law, a system of jurisprudence antedating the common law. ${ }^{36}$

In the opinion, great stress was given the fact that the Catholic Church imposes severe penalties on its members who do not do their uttermost to educate their children in accordance with its doctrines. The court may have felt that one marrying a Catholic would be aware of this pressure and, therefore, should be bound by the agreement.

The court laid down what it considered to be rules of law: (1) an antenuptial agreement is an enforceable contract having a valid consideration; (2) the court will take notice of the religious and moral obligations of the parties thereto; .(3) the spiritual training of a child among members of its own faith is paramount over material considerations; (4) a holding that the religious training of a child can be dispensed with until it reaches maturity on the theory that it can then choose what religion it desires is repugnant to American background and traditions; (5) a court is bound to uphold the demand of a Catholic parent that a child of the marriage be brought up in the Catholic faith ;37 (6) the court will take notice that the Catholic Church is the only

\footnotetext{
${ }^{33}$ It is difficult to see what relation these "fundamental princlpleg" have to a legal analysis of the problem. As to the statement regarding the canon law, while it is interesting, and perhaps true, it had little to do with the solution of the problem. The American system of law is not based on the canon law. After considering the concept of consortium, the court said that upon the marriage of the partieg, the agreement became an inseparable part thereof.

37 Apparently, the court meant that the demand of the Catholic parents would be upheld even in the absence of an antenuptial agreement.
} 
church binding its members to its laws under the penalty of excommunication; and (7) the fact that the child is for a time trained in violation of the contract does not invalidate the contract. ${ }^{38}$

The most recent American case appears to be Shearer $v$. Shearer..$^{39}$ The agreement was said to involve more than internal affairs of the home and to the father, the matter was not only one of spiritual welfare but one of strong public policy. The court said that while the welfare of the child was the controlling consideration, ${ }^{40}$ its welfare would not be adversely affected by enforcement of the agreement since the child had not reached the age where religious instruction would have had any effect on it. The antenuptial agreement was said to have been an inducing cause of the marriage and an enforceable contract which should be upheld, everything else being equal. The father was given the right to take the children to church for religious instruction when they became four years old.

It might be argued that Ramon and Shearer are of little force even in the New York courts, for they are lower court decisions. But in view of the fact that there has been dictum in the New York appellate courts to the effect that such agreements are enforceable ${ }^{41}$ and that for approximately forty years the lower courts have said such agreements were enforceable, ${ }^{42}$ there would seem to be adequate basis for a contention that the settled New York rule is that antenuptial agreements for the religious instruction of children are of legal significance.

\footnotetext{
ss Evidently, this was intended to include the type of cases where other courts had held that violation of the agreement coupled with indoctrination of the child in principles of religions other than that agreed upon resulted in a situation where to enforce the agreement would be to endanger the child's welfare.

20 Supra, n. 35. The agreement was between a Protestant woman and a Catholic man. A child was born. The mother brought an action for separation and maintenance.

¿ This could be construed as somewhat of a retreat from the militant view of the Ramon case.

¿Weinberger v. Vau Hessen, 260 N.Y. 294, 183 N.E. 429 (1932).

12 In re Lamb's Estate, 139 N.Y.S. 685 (1912).
} 


\section{Conclusion}

From a nose count of the American cases, it would appear that the weight of authority is that an antenuptial agreement for the religious instruction of children is a legally . enforceable contract. It might be argued, however, that ordinary contract principles are not applicable to this type of agreement as it is not an ordinary commercial contract but one dealing with spiritual matters which calls for a different analysis and treatment. But from the ordinary contract standpoint, a court would have little difficulty in finding the necessary promises, be they expressed or implied. It is well settled that marriage or a promise thereof is sufficient consideration to support a contract. ${ }^{43}$ Constitutional objections to enforcement seem to be absent. ${ }^{44}$

The question of enforceability boils down to one of policy. This aspect of the problem should be considered on the assumption that other factors are equal and that a decision one way or another as to enforceability of the agreement will not adversely affect the welfare of the child, for if the child's welfare is endangered, that should be the paramount consideration rather than some technical legal right of the parent.45 It might be argued that this "welfare of the child"

${ }^{* 3}$ It is not necessary to cite cases on this point as their numbers are legion.

"U.S. Const. Amend. I provides that "Congress shall make no law respecting an establishment of religion or prohibiting the free exercise thereof." Whether this is picked up and applied to the states by AxreND. XIV would appear to be immaterial as no law is being made. If it were argued that some provision of AMEND. XIV $\$ 1$ is being violated as to the child, tbe answer might well be that "Liberty of conscience is a fundamental right. . . But this pertains only to those who have reached majority or mature judgment." In re Jacquet, 40 Misc. 575, 82 N.Y.S. 986 (1903). The Ramon case expresses a similar view. To a protesting parent contending that he or she was being deprived of religious freedom, in some way or other, it could be said that such parent was cognizant of the provisions of the agreement when it was signed. Such parent was, as a prospective spouse, faced with the alternative of abstinence from the particular marital relationship or of entering into an agreement relating thereto. The latter alternative was chosen. On what constitutional grounds should the party be heard to complain?

ts Hernandez v. Thomas, 50 Fia. 522, 39 So. 641 (1905). By now, it will have been noted that in the majority of the cases, the welfare of the child has been held to be the matter of first concern. 
rule makes an agreement useless, but this is not necessarily so, e.g., where the child is raised in accordance with the agreement until suit is brought. If the child has not been raised as provided in the agreement, the rights arising thereunder would probably be considered waived. Where the child is raised in the specified faith until termination of the marriage or the death of a party thereto and thereafter the child is brought up in violation of the agreement for a period of time, it would probably be held that a party seeking to enforce the agreement after such a lapse of time would be barred by laches. In both of the latter situations, the agreement could be held unenforceable without resort to the welfare of the child rule, and it would seem that the rule would only be applicable in those situations.

It may be urged that it is against sound public policy for a court to assist in the perpetuation of religious views from one generation to the next. ${ }^{46}$ This ignores the fact that no matter what the decision is, the court in effect is perpetuating the religion of one of the parties. To hold the agreement unenforceable would, in a negative way, be to perpetuate the religious view of the promising spouse from one generation to another. The court might be said to "be in a box," for whichever way it turns, it is favoring one religion or another. This policy argument appears to be of doubtful value.

It has been said that "public policy is against the permanent transfer of the natural rights of a parent."47 Assuming that a parent has some "natural rights" and further that the religious instruction of children is such a right, why is public policy against its permanent transfer? The logical result is that in a mixed marriage there would be two competing "natural rights" - the right of each parent to have the child brought up in his or her particular religion. Unless some adjustment is made between these "rights" conflicts may arise. Public policy seems to favor peaceful adjustment of possible sources of conflict. The antenuptial agreement would appear to be such an adjustment or compromise, and,

16 State v. Bird, 253 Mo. 569, 162 S.W. 119 (1913).

4 Cited with approval in Brewer v. Cary, supra, n. 18. 
therefore, it should be favored by public policy. Again, the policy argument appears weak.

Perhaps the strongest policy argument against enforcement of the agreement is the alleged difficulty attendant upon judicial intervention in the family relation. Courts feel that it is not their duty to direct upbringing of children ${ }^{48}$ or to oversee the thinking of parents. ${ }^{49}$ A court cannot regulate the internal affairs of the home. ${ }^{50}$ Obligations, rights and duties which are moral in nature are not proper subjects of equitable relief.51 Endless difficulties would arise should courts attempt to tell parents how to bring up their children. ${ }^{52}$ Injunctive relief in family relations only result in making ridiculous the court granting the decree. ${ }^{53}$ This policy argument may be challenged on the ground that when enforcement of the agreement is sought, there is no longer a family relation. The parties have usually separated. ${ }^{54}$ A disagreement is brought before the court. The issue should be faced up to and settled in one way or another. Cantankerous parents with a problem which cannot be settled by the judiciary would present an interesting and unusual problem. A court would seem as well qualified to decide the point of disagreement as would anyone else.

Two methods of enforcement might be through the doctrine of promissory estoppel ${ }^{55}$ or by invoking the aid of the ecclesiastical courts. The latter alternative would be of

${ }^{23}$ Application of Goldfarb, 6 N.J.Super. 54370 A.2d 94 (1949); Noll v. Noll, 277 App.Div. 286, 98 N.Y.S.2d 938 (1950).

to Application of Goldfarb, 6 N.J.Super. 543, 70 A.2d 94 (1949).

so Sisson v. Sisson, 271 N.Y. 285, 2 NE.2d 660 (1936).

51 Bartholemew v. Workman, 197 Okla. 267, 169 P.2d 1012 (1946).

62 Sisson v. Sisson, 271 N.Y. 285, 2 N.E.2d 660 (1936).

${ }^{63}$ Bauman Y. Bauman, 250 N.Y. 382,165 N.E. 819 (1929).

st See the Ramon, supra $\mathrm{n} .17$, and Shearer, supra, n. 35 cases. None of the cases, English or American, involved, at least from the reported facts, the situation contemplated when the courts see difficulty-an existing family unit. The cases indicate that the parties had separated and had heen in difficulties for some time before the question of en. forcing the agreement arose.

is "... promises which often seem to have been intended as gratuitous have been enforced when a marriage has taken place in reliauce upon them." Wirliston, Contracts, 500 (1936 ed.). See, p. 4939, n. 3 where it is said that antenuptial agreements for the religious instruction of children are generally upheld in this country. 
value in a jurisdiction holding the agreement to be unenforceable. It may be summarized as follows: (1) membership in a church carries with it submission to the organization's ecclesiastical jurisdiction which is primarily contractual in nature $;^{56}$ (2) an ecclesiastical court has jurisdiction as to matters of faith, creed or discipline ;57 (3) a decision of an ecclesiastical court in a matter of which it has jurisdiction is final and will not be reviewed by the civil courts; 58 and, (4) the aid of the civil courts may be invoked to secure enforcement of or to enjoin interference with an ecclesiastical decree. ${ }^{68}$

It is arguable that an antenuptial agreement for the religious instruction of children would fall within the above pattern. The main hurdle would be in finding contractual submission to the ecclesiastical jurisdiction. This might be surmounted if signing the agreement were deemed to constitute an implied submission to the ecclesiastical jurisdiction of the church in matters of faith, creed or doctrine arising therefrom. There is authority for the proposition that the agreement raises matters of faith. ${ }^{60}$ It would seem that once a decree favorable to enforcement was obtained from the ecclesiastical courts, recourse could be had to the civil courts for enforcement thereof or for a decree of noninterference therewith. ${ }^{61}$ While a civil court might not accept this method of enforcement, a practitioner confronted with a local rule that the agreement is without legal significance might be wise to attempt it. ${ }^{62}$

to Ramsey v. Hicks, 174 Ind. 428, 91 N.E. 344 (1910); White Lick v. White Lick, 89 Ind. 136 (1883); Thomas v. Lewis, $224 \mathrm{Ky} .307,6$ S.W.2d 255 (1928); Bear v. Heasley, 98 Mich. 279, 57 N.W. 270 (1893); Trustees v. Halvorsen, 42 Minn. 503, 44 N.W. 663 (1890).

67 Watson v. Jones, 13 Wall. 679 (U.S. 1871). In addition there are numerous state decisions on the point.

cs See, supra, n. 57.

to 73 Sor.J. 440 (1929). See, Dwenger v. Geary, 113 Ind. 106, 14 N.E. 903 (1888).

0 In re Jacquet, 40 Misc. 575, 82 N.X.S. 986 (1903); Ramon v. Ramon, supra, n. 17.

a "It is perhaps not generally understood that the Ecclesiastical Courts are ohliged to rely for the enforcement of their judgments ('admonitions') upon the arm of the civil power. 73 Sox.J. 440 (1929).

a. For the forms to be used in the Catholic courts, see, 6 JURIST 68 (1946). 
In conclusion, it may be said that the antenuptial agreement itself lacks some of the trappings of an enforceable contract.63 The Protestant party promises "on my word and honor." On the face of it, the agreement could be said to be one to which the parties themselves attached no legal significance. It just is not contract language. In addition, the promise seems to run to no one in particular. ' It would appear that if the agreement is to be recognized as being legally enforceable, a thorough revision thereof is necessary. ${ }^{64}$

The present agreement is in two parts. In the first, the Catholic party promises to continue his or her religion and to work for the conversion of the other party. The agreement signed by the non-Catholic party reads:

" $I$, the undersigned, wishing to contract a marriage with the above mentioned Catholic, propose to do so with the understanding that the marriage bond thus contracted is indissoluble, except by death. Aud I promise, on my word and honor, to fulfill the conditions required by the Catholic Church in granting a dispensation, namely:

1. That the marriage ceremony will be performed by a Catholic priest and that no other marriage ceremony will either precede or follow that by the Catholic priest.

2. That the said__.___._._._Catholic Party] shall not be hindered in any way in the free exercise of his/her religious duties.

3. That all the children of either sex born of this marriage shall be baptized and educated in the Catholic Faith and according to the teachings of the Roman Catholic Church.

not baptized [non-Catholic party] baptized in denomination Address (No. and Street) (Town) (State)

The date of the proposed marriage is.

$$
\begin{aligned}
& \text { Rev. } \\
& \text { Church. } \\
& \text { Location. }
\end{aligned}
$$

eI A revision of the part signed by the non-Catholic party along the following lines might be helpful, and it might be well to have it on a separate page from that signed by the Catholic party.

"I, the undersigned, wishing to contract a marriage with the aforementioned Catholic party, propose to do so with the understanding that the marriage bond thus contracted is indissoluble, except by death. In consideration of the said Catholic party entering into the marital rela. tionship with me, I hereby promise the said Catholic party to fulfill the 
conditions prescribed by the Catholic Church in granting a dispensation for the marriage; in addition, in consideration of its granting the said dispensation, I hereby promise the said Catholic Church to fulfill the conditions prescribed by the said Catholic Church in granting the said dispensation for marriage, namely: ... (See the conditions in the original agreement in $n$. 63.) ... In further consideration of the said Catholic party entering into the marital relationship with me; and in further consideration of the said Catholic Church granting a dispensation for the said marriage, I further promise the said Catholic party and the said Catholic Church that should any disagreement occur regarding the religious instruction of any children which may be born of the said marriage, such disagreement shall be submitted to the Ecclesiastical Courts of the said Catholic Church for determination and/or decision, and I further promise and agree to accept the determination and/or decision of the said Courts and be final and binding upon me.

I hereby acknowledge that it is my intention that the promises contained herein be legally binding and enforceable in the secular courts at the suit of the said Catholic party or the suit of any or all baptismal God-parents of any or all of the children which may or shall be born to the said marriage."

[non-Catholic party]

The instrument could be concluded by appropriate formalities attendant on signature. It is submitted that this would surmount the objections that the language is non-contractual, the promise runs to no-one in particular, the parties did not intend a legal contract, and that the nonCatholic party has not submitted to the jurisdiction of the church. Such a form would seem to bind the promising party to submit a dispute to the ecclesiastical courts-an arbitration agreement as it were. The denomination of the promising party as well as the information as to the priest could be well omitted in order that any religious tinge be minimized. 